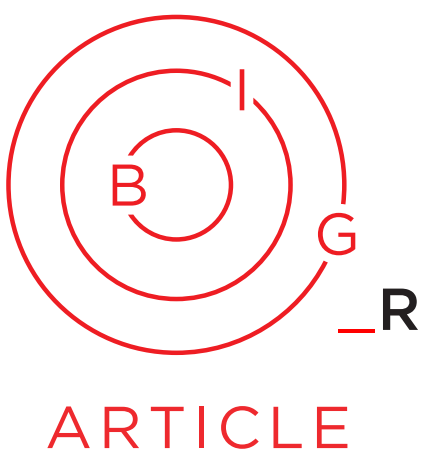

Borders in Globalization Review

Volume 1, Issue 1 (Fall 2019): 43-53

https://doi.org/10.18357/bigr11201919258

\title{
Cross-Border Cooperation in the Carpathian Euroregion: Ukraine and the EU
}

\section{Tatiana Shaban*}

\begin{abstract}
Cross-border cooperation among the Eastern neighbours of the European Union can be understood as a new approach to public policy and border governance in the region. There was no border cooperation strategy between communist and European countries during Soviet times. The question of the management of the Eastern border of the EU, especially with Belarus, Ukraine, and Moldova, came on the agenda in 1997, when accession to the union was finally opened to Eastern and Southern European candidates. With the Partnership and Cooperation Agreement that came into force in 1998, Ukraine signalled its foreign policy orientation as European, asserting that Western integration would help modernize its economy, increase living standards, and strengthen democracy and rule of law. The European Commission required "good neighbourly relations" as a further condition for accession and in conjunction, the concept of "Wider Europe" was proposed to set up border-transcending tasks. The Carpathian Euroregion was established to contribute to strengthening the friendship and prosperity of the countries of this region. However, the model was not fully understood and had only limited support of the national governments. This article uses the Carpathian Euroregion as a case study to show that overall Ukraine and the EU's Eastern neighbourhood presents more opportunities for effective cooperation with the EU rather than barriers or risks.
\end{abstract}

\section{Introduction}

Border politics of the European Union (EU) is a complex range of programmes, policies and imaginaries of the political community in which borders are used as resources for different specific aims. The question of the management of the Eastern border of the EU, especially with Belarus, Ukraine, and Moldova, came on the agenda in 1997, when the prospect of accession was finally opened to Eastern and Southern European candidates. The European Commission (henceforth, the Commission) required "good neighbourly relations" as a further condition for accession and in conjunction the concept of "Wider Europe" was proposed to set up border-transcending tasks. The overall objective of the policy was to draw both old and new neighbours closer into the EU's political, economic and cultural realm, short of full membership. It implied increasing openness and inclusionary politics where the neighbourhood could be jointly negotiated between the EU and its regional partners. The first financial instruments, including the European Neighbourhood Policy Instrument (ENPI), in the framework of the ENP, additionally suggested that "Wider Europe"1 aimed at blurring the EU's external borders. In the post Cold War context, Wider Europe was seen to represent a new spatial imaginary that went beyond the old East-West divide (Liikanen, Scott \& Sotkasiira 2016, 2), To sum

\footnotetext{
* Tatiana Shaban, PhD, is non-resident fellow at the Centre for Global Studies, University of Victoria, Canada. Contact: tshaban@uvic.ca
} 
Borders in Globalization Review | Volume 1 | Issue 1 | Fall 2019

Shaban, "Cross-Border Cooperation in the Carpathian Euroregion"

up, the original proposition of a policy towards the EU's neighbours was very much linked to the idea of reinforcing sub-regional cooperation, especially in creating an "Eastern Dimension"-and, later on, Black Sea cooperation (to complement the already existing "Northern Dimension" and the "Union for the Mediterranean"). In turn, Ukraine formalized its foreign policy posture as European since the Partnership and Cooperation Agreement (PCA) came into force in 1998 and asserted that European integration would help modernize its economy, increase living standards, and strengthen democracy and rule of law. Hence, this paper assumes that European integration (with or without EU membership) is good for Ukraine.

According to the Commission, governance beyond EU borders means establishment and operation of "institutions" (in the sense of rules of the game), which define actors and their responsibilities, both in cooperation towards society's objectives and in the resolution of any conflicts that may arise. From 2011, the EU has initiated various forms of governance-supporting local initiatives, diversifying stakeholders, and speaking to all levels of society (Casier et al. 2013). Therefore, the change that is occurring in governance policy cannot be fully grasped without considering the importance of border governance and its impact on the local border communities outside the EU.

In Ukraine, the regional topic remains a prominent feature of the state's policy since the country gained its independence in 1991. Ukraine has only existed in its present boundaries since World War II. Before, the current territory of western Ukraine had no experience of Soviet rule and had never been a single state within the Ukrainian Soviet Socialist Republic, which was established in 1922. Western Ukraine (Eastern Galicia, Volyn' and Northern Bukovina regions) was annexed by the Soviet Army in 1939 based on the Molotov-Ribbentrop Pact with Zakarpattia or Transcarpathia region added to Ukraine in 1946. As a result, regional political, economic and cultural disparities became one of the biggest problems for independent Ukraine. Moreover, after the collapse of the Soviet Union, Eastern Ukrainian economic and cultural links inherited from Soviet times remained very strong and heavily dependent on exports to Russia (Kolossov \& L. Van Well 2016). Last but not least, Ukraine, torn between two region-building projects of the EU in its Eastern neighbourhood and Russian Federation in its post-Soviet space, experienced Russian military intervention in the Donbass region of Ukraine in the last decade.

Ukraine's movement toward European integration emphasized cross-border cooperation (CBC). This referred to joint action aimed at developing economic, social, scientific, technical, environmental, cultural and other relations between local communities and their representative bodies, local executive authorities and relevant authorities of neighboring states within competences defined by respective national legislation (Law of Ukraine 2004, 2015). The Law of Ukraine on CBC defines its basic concepts, purposes and principles, as well as organisational and governmental forms of support. Local municipalities and regional authorities become responsible for assisting enterprises to develop external economic links and export potential, as well as international cooperation, including the establishment of joint ventures. Likewise, the Concept of the State Regional Policy ${ }^{2}$ in Ukraine directly influences $\mathrm{CBC}$ by stipulating that the powers of local authorities need to be strengthened. The legal basis of Ukraine-EU dialogue on regional development, regional and cross-border cooperation is based on Article 70 of the PCA and defined by the chapter "Cross-Border and Regional Cooperation" of the Association Agreement. It has been argued that $\mathrm{CBC}$ activities contribute to transforming the operation of power across the various levels of governance and a "new mode" of governance emerges from this development (Delcour 2001; Kramsch \& Hooper 2004; Liikanen, Scott, Sotkisiira 2016). From the EU side, to effectively cooperate and understand actors and rules of the game in the Eastern neighbourhood, it needs to be a responsible cross-border manager as well as a good strategic actor in the international arena.

On 14 February 1993 the Ministers of Foreign Affairs of Hungary, Poland, Slovakia and Ukraine (Romania would join in 1997 with the last county accepted in 2000) ratified a declaration in the Hungarian city of Drebecen, stating that the establishment of the Carpathian Euroregion (CE) would greatly contribute to strengthening the friendship and prosperity of the countries of this region and would guarantee active application of the principles of the Helsinki Act (1975), the Charter of Paris for a New Europe (1990), and other instruments. Ukraine also joined the European Outline Convention on Transfrontier Cooperation between Territorial Communities or Authorities in 1993. Euroregions are normally defined as organizations of border (transboundary) interregional (intermunicipal) cooperation aimed at establishing good neighbourly relations as well as addressing common problems singled out by constitutional documents regulating the territories of three or more states (Council of Europe 1980). They represent institutional structures set up by two or more states to support cross-border cooperation, and as such represent a framework for meeting the needs for participation, transparency and development of cooperation strategies (Gasparini 2017).

Within the framework of the Euroregion, Ukraine and EU member states are also reaching general European level. In the case of Ukraine, which is 
Borders in Globalization Review | Volume 1 | Issue 1 | Fall 2019 Shaban, "Cross-Border Cooperation in the Carpathian Euroregion"

implementing the Association Agreement and Deep Cooperation and Free Trade Agreements with the $\mathrm{EU}$, the union acts as a transformative power, aiming to promote reforms across a broad spectrum of governance areas: rule of law, public administration, democratic institutions, economics, and various standards and regulatory issues. However, largely due to the lack of strategic vision for the development of the Carpathian Euroregion (CE) and other operating Euroregions in Ukraine, examples of practical cooperation at the EU level have been very limited. According to Mytryaeva (2007), in order to succeed in integration efforts, it is necessary to have effective executive structures with a certain legal status at various levels within the Euroregion structure. This paper is an examination of Ukraine's current course of European integration within the framework of the Carpathian Euroregion (CE), from the viewpoint of cross-border governance. Likewise, it questions the governance of borders in Eastern Europe and specifically the role of the EU in it.

This article uses SWOT analysis to analyse strengths $(\mathrm{S})$, weaknesses $(\mathrm{W})$, opportunities $(\mathrm{O})$ and threats ( $T$ ) for EU governance within the framework of the Carpathian Euroregion. The method is based on identifying and measuring internal and external indicators of a cross-border area, making it possible to evaluate them as positive or negative, according to the intensity of their presence.

The article is structured as follows. Section one reviews historical development of the Carpathian Euroregion by exploring the progress of Ukrainian integration with the EU. Section two reviews relevant literature debates and shows how existing institutional mechanisms and cross-border cooperation instruments influence the European integration course of Ukraine-if at all. Section three defines the organisational structure of the Carpathian Euroregion and offers a review of the SWOT method for analysing major CBC tendencies in Ukraine. Finally, the paper's conclusion summarizes the impact of cross-border cooperation in the context of the Euroregion on the transformation of Ukrainian public/state policies and identifies major issues arising.

\section{1: Historical Development of Carpathian Euroregion and the European Integration Course in Ukraine}

After the fall of Communism, citizens and institutions of the Ukrainian borderlands found themselves confronted with tough processes of re-scaling and re-territorializing. As mentioned above, CBC policy with the EU is a reasonably new policy for Ukraine. The aim of cross-border cooperation has been defined as the development of social, economic, academic, technical, cultural and other relations, including good neighborly relations among its actors and participants on the principles of sovereignty, territorial integrity and inviolability of state borders; considering power and authority of the subjects of CBC during conclusion of relevant agreements; coordinated removal of political, economic, administrative and other obstacles for mutual cooperation (Article 2, Law of Ukraine for "Cross-Border Cooperation"). Ukrainian bordering territories enter into four Euroregions ${ }^{3}$ at the same time: the largest of these is the Carpathian Euroregion (CE) which unites territories of four EU member states as well as the Transcarpathia, Lvivska, Ivano-Frankivska, and Chernivetska regions of Ukraine. Mytryaeva (2007) envisions Euroregions as an instrument of external policy of sovereign countries, which aspire to establish and maintain good neighbourly relations on a regional (municipal) level. According to her observation, it was due to activity within the framework of the Euroregions that territories of the Eastern Carpathians, at the watershed of the Tisza river, were not turned into a conflict zone. In fact, at present, the Carpathian region is one of the most stable regions in Eastern Europe. Transcarpathia also made its first successful steps by using Euroregions as an integration instrument.

The CE was founded as a mechanism of cross-border regional cooperation between several post-communist countries-Poland, Slovakia, Ukraine, Hungarywhich signed an agreement on the formation of the international association named the Carpathian Euroregion in 1993, with Romania joining in 1997. It was the only Euroregion in Europe which included the bordering territories of five post-communist states characterized by different economic development and with heterogeneous ethnic, religious, and cultural structures (Mytryaeva 2007, 126). In the 20 th century, this area was governed by six successive entities (the Austro-Hungarian Empire, Czechoslovakia, Poland, Hungary, the Soviet Union, and Ukraine) with occasionally shifting borders. At the

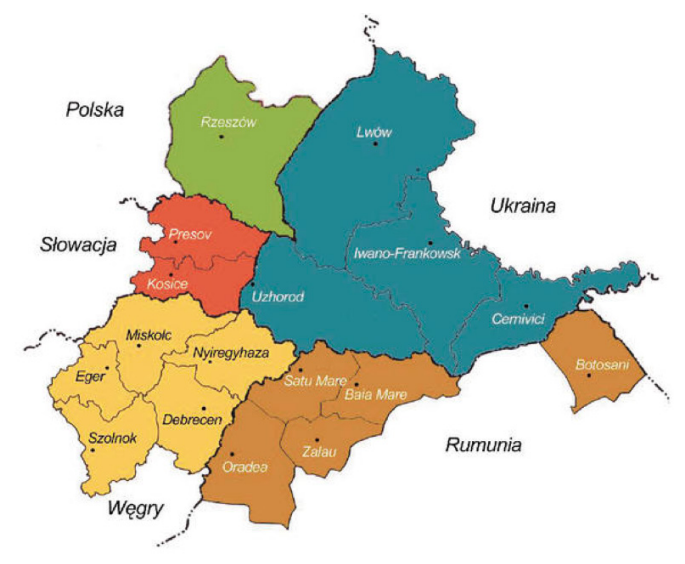

Figure 1. Carpathian Euroregion. Association of European Border Regions. Source: https://www.aebr.eu. 
Borders in Globalization Review | Volume 1 | Issue 1 | Fall 2019

Shaban, "Cross-Border Cooperation in the Carpathian Euroregion"

beginning of the 20th century, most parts of Ukraine belonged to the Russian Empire, and the rest to the Austro-Hungarian Empire. In 1919, the International Conference in Paris made Eastern Galitsia a part of Poland. In 1921, according to the Riga Agreement, the western part of Volynska oblast also became a part of Poland. The Russian part of Ukraine joined the Soviet Federative Socialist Republic in 1922 and became one of the Soviet socialist republics. In the five states, various nationalities lived together in a heterogeneous area that was also characterized by a mixture of major religions (Orthodoxy, Greek Orthodoxy, Roman Catholicism, Calvinism, Protestantism, Judaism, and Roma) (Tanaka 2006, 65). Together, all of these features characterize the area as "a mosaic zone of ethnicities, cultures and religions" and "a microcosm of new Europe" (Research Center of the Slovak Foreign Policy Association 2001a, 6-11). Today Ukraine remains the only state within the Carpathian Euroregion framework with clear aspirations for EU integration.

EU programmes for its neighbourhood gained a separate status and a budget in 2007-2009 within the Eastern Partnership (EaP) policy framework. The EaP policy of the EU was adopted in 2007 and directed at Armenia, Azerbaijan, Belarus, Georgia, Moldova and Ukraine. Before 2007 the regions of Ukraine (Volynska, Lvivska, Transcarpathia, IvanoFrankivska, Chernivetska, and Odeska) were subject to the TACIS ${ }^{4}$ programme. In 2007 the ENP began to replace earlier EU programmes to intensify CBC between its border and neighbouring regions and improve resource allocation to allow local communities to advance more efficiently. An important element of coordination between Ukraine and the EU was the involvement of Ukraine's regions on a regular basis in activities of European regional associations, in particular the Assembly of the European Regions, Council of European Municipalities and Regions, Conference of European Regional Legislative Assemblies, Association of European Border Regions, Conferences of Peripheral Maritime Regions, European Association of Elected Representatives from Mountain Areas, and EUROCITIES.

Depending on the nature of specific projects, the $\mathrm{EaP}$ initiative allocates funds to various beneficiaries. Comprehensive Institution-Building projects, public administrations of partner states, EU member states, and EU institutions use specific instruments in training and other institutional reform programmes: Twinning, Technical Assistance and Information Exchange (TAIEX), and EU advisory missions. For Pilot Regional Development Projects, beneficiaries include public administrations of partner states, local authorities, small and medium enterprises, and non-governmental organisations. Funding, foreseen in the amount of $€ 75$ million, started in 2012 from the 2012/2013 ENPI budget of $€ 62$ million. As preparatory steps, EU missions were organized to five EaP countries, except for Belarus, in April-May 2011, to inform stakeholders about the concept, and a seminar was organized in Brussels in June with representatives from partner countries and EU Delegations to launch the programme. It is the task of the regional and local partners on both sides of the border to analyse their common needs and to identify priorities and actions, most relevant to their local situation. The ENPI, ${ }^{5}$ the financial instrument employed for ENP and addressed to ENP partner countries, offered co-funding for promoting good governance and equitable social and economic development process. In the perspective of reinforcing cooperation with countries bordering the EU, the ENPI included a component specifically targeted at CBC. CBC's strategy has four key objectives: (1) to promote economic and social development in border areas; (2) address common challenges; (3) ensure efficient and secure borders; and (4) promote people-to-people cooperation.

The management of $\mathrm{CBC}$ programmes was assigned to a local or national authority jointly selected by all participating countries. CBC is also financed by the European Regional Development Fund. For example, the EaP Territorial Cooperation Support Programme promotes sustainable cross-border cooperation between border regions of EaP countries by building the capacities of local and regional authorities to effectively manage cross-border programmes in the region. The time frame of the period between 2012-2015 had a budget of $€ 5.5$ million (Regulation of the EP and of the Council on ENPI, 2006; Executive Summary of the ENPI CBC Strategy Paper, 2007). CBC used an approach largely built on Structural Funds principles such as multiannual programming, partnership, and co-financing, adapted to take into account the specificities of the Community's external relations rules and regulation. One major innovation of the ENPI $\mathrm{CBC}$ lied in the fact that the programmes involving regions on both sides of the EU border shared one single budget, common management structures, and a common legal framework and implementation rules, giving the programmes a fully balanced partnership between the participating countries.

The ENPI supported cross-border and trans-regional cooperation as well as gradual economic integration of recipient countries with the EU beneficiary countries. In 2011-2012 the ENPI CBC Programme with a budget of $€ 500,000$ implemented a project with a focus on training activities enabling job placement for the disadvantaged population in Beregovo (Ukraine) and Miskolc, Hungary. The overall objective of the action was to contribute to the intensification and deepening of cooperation between institutions in Zakarpatska, Ukraine and Hungary. As a result, unemployed people (especially Roma, women, 
Borders in Globalization Review | Volume 1 | Issue 1 | Fall 2019 Shaban, "Cross-Border Cooperation in the Carpathian Euroregion"

and the disabled) gained new skills to successfully apply for jobs in Miskolc and Zakarpatska regions. A further benefit was that the initiative strengthened regional and institutional cooperation between Miskolc and Beregovo. CBC also set up a network of civil society organizations in the $\mathrm{EU}$ and partner countries. EU assistance in this area provided administrative and financial support for cooperation across the region and sub-regions between various civil society organizations. The Conference of Regional and Local Authorities (CORLEAP) ${ }^{6}$ was established by the Committee of the Regions (CoE) in 2011 to bring a regional and local dimension into the EaP. It brought together thirty-six regional and local elected representatives from the EU and EaP countries. President of the European Committee of the Regions and CORLEAP co-chair Ramón Luis Valcárcel Siso stressed that an important factor enabling multi-level governance to function effectively was greater political and fiscal autonomy for regional and local authorities. The three EaP priorities of public administration, fiscal decentralization, and regional cooperation were addressed in a report submitted at the CORLEAP meeting in Lithuania in November 2013. CORLEAP members stressed that decentralization and territorial cooperation were key to a successful implementation of the Association Agreements and economic, political, and social development. According to Michel Lebrun, a CoR President and CORLEAP co-chair, "decentralisation reforms and more cross-border cooperation" can lead "to greater legitimacy of policies on the local level and provide concrete solutions to problems for people living on both sides of a frontier" (the Annual Meeting of the CORLEAP, 2014).

The well-known EaP instruments for institution-building also supported the authority's administrative capacity to implement $\mathrm{CBC}$ policies at both local and national levels. They included TAIEX, Twinning, ${ }^{7}$ Support for Improvement in Governance and Management (SIGMA) for the European Neighbourhood region, and recent comprehensive institution-building programmes. The EaP obviously created new multilateral institutions in EU policy towards the East (Delcour, 2011). However, in parallel it drew the line for reinforcement of bilateral cooperation at various levels, i.e., of the contractual relations with the neighbours through the negotiation of Association Agreements, Deep and Comprehensive Free Trade Agreements, visa liberalization, cooperation in the field of energy, support to social and economic policies, and finally assistance aimed at strengthening institutional capacities in order to meet the requirements of negotiated agreements.

\section{2: Literature Review}

As an international association, the Carpathian
Euroregion is defined as a consultative and coordinating body directed at the expansion of transboundary cooperation of its member states and between different stakeholders at local, regional, cross-border, national, and supranational levels. The Ukrainian bordering territories enter into the four euroregions. The Carpathian is the largest; it unites the territory of four member states as well as Transcarpathia, Lvivska, Chernivetska and Ivano-Frankivska regions of Ukraine. Scholarly literature analyses the Carpathian Euroregion as an evolutionary form of governance, meaning that the established institutions can produce bottom-up initiatives in the border region and as an EU integration mechanism: a border regime or a builder of bridges. The bordering states to the east of the EU were actively involved in various transboundary projects of a bilateral and multilateral nature. In 2004 the EU Task Force, which comprised representatives of Ukraine, Central European neighbours, and EU experts, started ENP cooperation projects, among them Poland-Ukraine-Belarus, HungarySlovakia-Ukraine, and Romania-Ukraine. However, according to Mytryaeva (2007), the Lvivska region, for example, was cooperating more or less actively with Polish regions mostly on a bilateral level. Therefore, she concluded that Euroregions did not live up to the set expectations, directed at transboundary cooperation, due to established structures which were functioning on a community project basis (Mytryaeva 2007, 122-136).

Ukraine was involved in a smaller number of project applications compared to Poland and Hungary. Being EU members, Poland and Hungary applied for thirty-to-forty projects every year, whereas Ukraine applied for only two or three. Sotnikov and Kravchenko (2013) argue that Euroregions did not use their full potential as organizational forms of CBC whose task was to facilitate obtaining funds for cross-border co-financing projects from structural funds and other international financial institutions. However, they point out that cross-border industrial zones represented the main component of institutional innovation and an investment model for economic development not only of border areas but in the region as a whole.

Hungarian researcher Ludvig (2003) shows a number of negative factors affecting Carpathian Euroregion development: (1) differences in the context of the CE; (2) the size of the participating areas; (3) its structural institutional problems; (4) financial matters; (5) ambiguity of the division of labour between the district/local government and the central government; (6) historical inheritances; and (7) problems related to the introduction of the Schengen Acquis Communautaire. Likewise, the Polish agency of the CE (CE Secretariat) recognized that it faced three types of crises: first, a crisis of 
Borders in Globalization Review | Volume 1 | Issue 1 | Fall 2019

Shaban, "Cross-Border Cooperation in the Carpathian Euroregion"

self-recognition, which refers to a lack of knowledge, information, and consciousness; second, a crisis of representation, in which neither the low-level local self-governing bodies nor non-profit organizations nor private enterprises were able to send their representatives to both the Council of the CE and the national organization of the CE. The third crisis related to participation where local residents were completely uninterested in the CE's issues (Stworzyszenie na Rzecz Euroregionu Karpackiego Euro-Karpaty 2002, 11-17).

When it comes to governance issues, according to Tanaka (2006), firstly the CE must be examined by analysing the region's characteristics, as an evolutionary form of governance. Secondly, taking the perspective of public space encourages consideration of the degree to which the everyday economic space and the public space have been formed (Tanaka 2006). Kramsch and Hooper when examining cross-border governance in Europe conclude that cross-border areas in Europe were faced with the following four "dilemmas of multi-governance": (1) Euroregions were used as a convenient administrative policy for local elites to access funding sources from Brussels; (2) ties among economic actors were not developed automatically in the borderlands; instead, extensive economic relationships at the national and global levels outdid those of cross-border areas; (3) public awareness of crossborder initiatives was decreasing among locals of the Euroregion; and (4) it remained difficult to establish an effective democratic system of transboundary institutions (Kramsch \& Hooper 2004, 3).

These trans-border and trans-level actions alter the identity of the regional actors and precipitate the formalization and Europeanization of cross-border regions themselves. Takahashi (2006) emphasizes that although the boundary of the Euroregion was determined by the EU, the motivations and solutions of Euroregion participants vary depending on issues, resulting in an amorphous form of governance. However, by disregarding bottom-up initiatives of the region, the institutionalization of the Euroregion causes a problem. Van Kersbergen and Van Waarden (2004) note that in recent decades shifts in governance have occurred not just in the private, semi-private, and public spheres, but at (and in-between) the local, regional, national, transnational, and global levels. According to these authors, such changes take place in the forms and mechanisms of governance, the location of governance, governing capacities, and styles of governance. Overall, analysis of recent scholarly research on $\mathrm{CBC}$ and organizational-economic mechanisms shows that problems of development of interregional and transborder cooperation have received substantial attention. However, public space with multiple layers and multiple issues is not actively developed along the eastern border region of the EU.
According to scholarly research, the greater the density of interaction, the more likely it will generate behavioral change on the part of domestic actors, with outsiders working through informal coalitions and acting as the glue that brings together the domestic players that shape their reform preferences (Schimmelefennig and Sedelmeier 2005; Langbein 2015). There is no shortage of regional cooperation initiatives in the Carpathian Euroregion. However, for obvious reasons the CE model was not fully supported by the national governments. First, strongly centralized and oppressive states were not effective in pursuing policies and delivering public services. Second, Soviet legacy in Ukraine has long remained clearly visible in both the structure of local governing arrangements and in people's expectations of their authorities, as well as their lack of trust in the process of governing. This explains the strong sentiment that the state, rather than the community, should take care of people's needs. Third, ineffective unchanged governance processes triggered apathy and lack of responsibility in post-communist Ukrainian society. Therefore, the concept of autonomous self-governance as a form of local democracy was losing its support in Ukraine. In addition, citizens of Ukraine have little knowledge of local self-government, preferring either to passively wait for the resolution of their problems by local authorities with state support, or to solve the problems by themselves with no consideration for the wider community (UNDP 2008, 29-30). All of these factors combined presented a key challenge for the effective delivery of EU programmes and initiatives directed at its Eastern neighbourhood.

\section{3: Organizational Structure of the Carpa- thian Euroregion and SWOT Analysis}

The CE is an organization for cross-border regional cooperation among 18 border autonomous units at a similar level (region, province, county) belonging to five East European countries (Makowski 1993; Rebisz 2003, 35-43 cited in Tanaka 2006, 67). According to the agreement, Interregional Association Carpathian Euroregion goals are to organize and coordinate activities that promote cooperation in the fields of economy, ecology, culture, science, and education with assistance in elaborating concrete projects, and to promote various contacts at different levels along with good neighbourly relations. The CE is composed of four parts: the Council with Presidium and Chairman, Secretary General, National Offices (Agencies), and Working Commissions. The supreme body of the CE is the Council, which consists of three representatives from each member country. The Council meets every six months. It discusses and unanimously accepts common projects and makes decisions on important topics relevant to cooperation (appoint- 
Borders in Globalization Review | Volume 1 | Issue 1 | Fall 2019 Shaban, "Cross-Border Cooperation in the Carpathian Euroregion"

ment, budget, and organizational changes). The Chairman is elected every two years to manage the session, representing the Council to the outside. The Secretary General (Executive Director) as well is elected every two years, has authority to present bill drafts to the Council and conducts daily cooperation activities. The CE has a network of national offices, each of which has the responsibility to maintain regular contact with the Council, dealing with all the cooperation initiatives and taking charge of one Working Commission's works.

Specific work is performed by Commission for Regional Development (its coordinator at the Hungarian side); Commission for Tourism (coordinator at the Polish side) and Environment (coordinator at the Hungarian side); Trade Development (coordinator at the Romanian side); Commission for Prevention of Natural Disasters (coordinator at the Slovak side); Commission for Social Infrastructure (coordinator at the Ukrainian side); and Audit and Control Committee (coordinator at the Hungarian side. Working Commissions have five fields of activity: regional development, environmental protection and tourism, social infrastructure development, trade exchange development, and auditing (Rebisz 2003, cited in Tanaka 2006). Every national party contributes an equivalent of 35,000 USD a year to the CE budget (Helinski 1999, cited in Tanaka 2006, 67-68).

The important issues for this paper are institutional, including challenges of improving efficiency. According to Article Three of the Charter of the Interregional Association "Carpathian Euroregion", its main objectives are: coordination and organization of joint activities; promotion of cooperation in economy, science, ecology, education and culture among its members; support in the implementation of cross-border projects in the conditions of common interest; promoting contacts among population of the territories included in the Euroregion, promotion of good neighborly relations among its members; cooperation with international institutions and organizations. At the beginning of the European integration, Slovakia launched National Conventions for European Integration in Moldova and Ukraine and the Centre of Transfer of the Slovak Experiences from the Accession Process at the Ministry of Foreign Affairs in Bratislava. Using standard tools and additional financial capacity, the International Visegrad Fund ${ }^{8}$ started with flagship projects aimed at the promotion of the Slovak Democratization and Transformation experience, development of regional cooperation, and support of civil society.

\section{SWOT Analysis of the Carpathian Euroregion}

The development strategy of the Carpathian Euroregion contains clearly defined priorities. It benefits from favorable natural and ecological conditions, a significant amount of relatively well-qualified labor force and most importantly, positive cooperative attitude with a strong desire of partnership with neighbouring states towards its western border. Major geopolitical challenges of the CE include its role in the Euro-Atlantic integration of Ukraine. The SWOT analysis method is based on identifying internal indicators of a cross-border area, as well as external ones. It is vital to subsequently measure indicators by making it possible to evaluate them as positive or negative, according to the intensity of their presence. Through complex data processing, SWOT analysis made it possible to define the conditions of $\mathrm{CBC}$ in a specific area and, at the same time, helped to highlight any potential for cooperation by working on the existing elements (Gasparini \& Ferluga 2005) so as to emphasize strengths (S) and opportunities $(\mathrm{O})$, while limiting the negative effects of weaknesses (W) and risks or threats $(T)$. SWOT analysis may be used in any decision-making situation when a desired state objective is defined. It may also be used in preventive crisis management. The SWOT method can be used to evaluate the 'strengths', 'weaknesses', 'opportunities' and 'threats' involved in any organizational activity. In this study, firstly the general position of SWOT analysis in the cross-border cooperation process is explained, secondly the components of SWOT are examined. Strategic planning allows an entity to be more proactive than reactive in shaping its own future; it allows any organization to initiate and influence, rather than just respond to, activities and thus to exert control over its own destiny (David 2003, 15).

Strengths of the Carpathian Euroregion consist of: (1) institutional factors for effective $C B C$ such as signatory of the European Outline Convention on Transfrontier Co-operation (Madrid, 21 May 1980); signatory of the 1995 Additional Protocol to the Madrid Convention; signatory of the 1998 Second Protocol to the Madrid Convention; internationally recognized borders; good institutional and legal framework (based on EU requirements). The CE is a potential EU Objective area which includes nature conservation, environmental protection, rural development, ethnic groups in a backward situation, educational infrastructure to be developed. Administrative factors for effective $C B C$ are among the factors of successful development of the CE and in their turn include official definition of cross-border areas and local authorities' co-operation with foreign partners. (2) Economic factors for cooperation include participation in Interreg/ Phare projects; efficient and well-connected infrastructure: road, rail, and waterway networks; and favourable natural environment for agricultural production; good conditions for thermal, hunting, and cultural tourism; a considerable number of the cheap relatively well-qualified labour force; ambi- 
Borders in Globalization Review | Volume 1 | Issue 1 | Fall 2019

Shaban, "Cross-Border Cooperation in the Carpathian Euroregion"

tions for recognition and application of effective mechanisms of a market economy; growing interest towards the opportunities offered by the EU; and proximity to countries of the Eastern neighbourhood and their markets. (3) Linguistic, cultural, and historical factors for $\mathrm{CBC}$ include common historical background; common language or knowledge of the neighbouring country's language; ratification of the 1995 Framework Convention for the Protection of Ethnic Minorities; tradition of cooperation; and established transboundary transport routes.

Weaknesses of the CE consist of: (1) institutional obstacles to $\mathrm{CBC}$, including state centralization; lack of adequate state/non-state structures; conflicting capabilities on either side of the border; restrictive legal regulations on cross-border relations; lack of credibility; low mutual knowledge and trust; different political orientations and insufficient financial resources. (2) The main economic obstacles include uneven development levels; weak or non-existing response to opportunities offered by $\mathrm{CBC}$; considerable distance from the national and Western European economic centres; limited local resources; and lack of financial resources for essential public expenditures. (3) Socio-cultural obstacles include presence of negative stereotypes; language barriers; weak accessibility; underdevelopment of tourism; and the small number of experts and professionals speaking foreign languages and mastering the situation along both borders. To add, weak points of the CE include its peripheral location, possibly adverse demographic trends, unemployment, and low income in general.

Opportunities (as external indicators) consist of the establishment and development of direct contacts between municipalities, local authorities, civic organisations and citizens. The border guards of both countries interact on a permanent basis clearly showing that it is worth developing channels of wide-ranging information and experience exchange. Therefore, given the similarity of problems faced by the authorities at the regional and municipal levels, it should be possible to introduce joint programmes and projects in the fields of personnel training.

Common threats (as external indicators) comprise Illegal trafficking and organized crime in the cross-border region; traffic jams and smuggling and corruption on the border. There is also strong migration in the border area, which may affect not only area's demographic structure but also its occupational skills structure. Additionally, central government bureaucracy hinders local agencies and authorities from launching their own cross-border projects and programmes. Therefore, participation of Ukraine (and other members of the CE) in the Schengen Area makes cooperation less dependent not only on national governments but also on various international arrangements. As a further threat, the falling of the CE behind the central regions of the member countries is increasing and a peripheral situation is mounting with marginalization problems where possibilities for self-government are becoming limited. Additional threats include increase of isolation due to the deterioration of accessibility: worsening of the state of public roads and the further loss of the role of railways. The website of the Ministry of Foreign Affairs of Ukraine provides only a few examples of practical cooperation: presentation of Dnipropetrovsk region in Brussels in April 2012 and presentation of Vinnytsa region in Brussels on 15 September 2011. There is no significant foreign capital in the region in following years, therefore, prospects for investment and practical cooperation are limited Thus, the function of the CE as an international bridge can be lost.

\section{Conclusion}

This article aimed to identify mechanisms, and benefits of cross-border cooperation in the form of Carpathian Euroregion in Ukraine. It intended to show how existing institutional mechanisms and instruments of $\mathrm{CBC}$ influence the European integration course of Ukraine. It highlighted potential strategies and policies that the EU adopted to make its role in the region more effective. However, largely due to the lack of strategic vision for the development of the Carpathian Euroregion, examples of practical cooperation at the EU level have remained limited. EU regional programmes address matters which do not fully correspond to Ukrainian national priorities. This reduces the effective partnership and limits its ownership by the ENP partners. The EU's contribution to strengthening its governance through regional programmes is also rather limited, reflecting the scarce resources allocated to these areas of cooperation.

It is not clear where the limits of the EU regional influence actually lie. Assuming that regional cooperation and increasing economic interaction are among the most important prerequisites for stability in the post-Soviet era, an important lesson can be drawn that the EU vision of regional partnership can thrive through a mutually shared vision of political social, economic and cultural engagement in neighbouring countries. To conclude, the role of the bordering territories of the Carpathian Euroregion in international cooperation is of great significance from governance perspectives, and in relation to the European integration course of the Ukrainian state. However, its further development needs fundamental institutional changes. This means greater EU attention to security sector and judicial reform, policing, infrastructure, energy, customs and border control, and the fight against corruption, as well 
as conflict mediation, democratization, reviving the economy and the formation of more effective strategy and mechanisms for cooperation with European structures.

\section{Annex 1: Abbreviations}

\author{
AA: Association Agreement \\ CBC: Cross-Border Cooperation \\ CE: Carpathian Euroregion \\ CoE: Council of Europe \\ CoR: European Committee of the Regions \\ CORLEAP: Conference of Regional and Local Authorities \\ DCFTA: Deep Comprehensive Free Trade Agreement \\ EaP: Eastern Partnership \\ ENI: European Neighbourhood Instrument \\ ENP: European Neighbourhood Policy \\ ENPI: European Neighbourhood policy Instrument \\ EU: European Union
}

INTERREG: cooperation programmes between regions funded by the European Regional Development Fund.

PCA: Partnership and Cooperation Agreement

PHARE: Poland and Hungary: Assistance for Restructuring their Economies

SIGMA: Support for Improvement in Governance and Management (for European Neighbourhood Region)

SWOT: Strengths, Weaknesses, Opportunities and Threats. TACIS: Technical Assistance for Commonwealth Independent States

The Ukrainian SSR: The Ukrainian Soviet Socialist Republic

\section{Annex 2: Data Collection}

Content documentary analysis is applied to various categories of primary documentary sources, as follows.

Ukrainian legislation: The Constitution of Ukraine has the highest legal force. Laws and other normative legal acts are adopted on the basis of the Constitution of Ukraine and shall conform to it; laws and legal acts of the Ukrainian Parliament (Verkhovna Rada); by-laws where laws are supplemented by so-called normative acts - regulations, instructions, decrees, and orders. These documents are issued by the Cabinet of Ministers of Ukraine (the highest executive authority), ministries, public bodies and committees, and local government bodies. Normative acts contain mechanisms for law implementation. The Cabinet of Ministers of Ukraine issues Regulations (legal acts of a normative nature) and Decrees (legal acts covering operational and ongoing issues that are not of a normative nature); and Presidential Decrees. Under the general provisions of the Constitution of Ukraine, the President is entitled to issue Decrees on all matters referred to his jurisdiction.

\section{Annex 3: Legal Framework}

The legal framework for the involvement of Ukraine's border regions in cross-border cooperation is well-developed and quite sufficient. It includes:

a. The Council of Europe acts: European Outline Convention on Transfrontier Cooperation between Territorial Communities or Authorities (ratified by the Decree of Verkhovna Rada of 14 July 1993) and European Charter of Local Self-Government (Ratified by the Act of Ukraine of 15 July 1997).

b. National legislation: Act of Ukraine on Local Self-Government (adopted 21 May 1997); Act of Ukraine on Local State Administrations (adopted 9 April 1999); Act of Ukraine "On Transfrontier Cooperation" (adopted 24 June 2004 and defining the objectives and principles of the national policies in the field of transfrontier cooperation; powers of Ukrainian entities involved in transfrontier cooperation; and the principles and methods of the government support to transfrontier cooperation including the national funding); Decree by the Cabinet of Ministers of Ukraine "On the Measures to Implement the Concept of the State Regional Policy" (adopted 13 September 2001); Decree by the Cabinet of Ministers of Ukraine "On Some Issues of the Development of Cross-border Cooperation and the Euroregions" (adopted 29 April 2002). The Law of Ukraine "On Fundamentals of State Regional Policy". 5 February 2015. No. 156-VIII1.

\section{Notes}

1 As such the concept seeks to "develop a zone of prosperity and a friendly neighbourhood - a 'ring of friends' - with whom the EU enjoys close, peaceful and co-operative relations" [COM (2003) 104]. It was the key document for the European Neighbourhood Policy (ENP) of the EU launched in 2004. In June 2006 the EU Council reiterated that the EU is open to any country that fulfils Art.49 of the European Treaty and would meet the conditions for membership.

2 The first legislative act that laid the foundation of the legal framework for the state regional policy was "The Concept of the State Regional Policy" approved by the Decree of the President of Ukraine No. 341/2001 on the 25th of May, 2001.

3 Article 2.1 of the 1980 Madrid Convention defines transfrontier co-operation as "any concerted action designed to reinforce and foster neighbourly relations between territorial communities or authorities within the jurisdiction of two or more Contracting Parties and the conclusion of any agreement and arrangement necessary for this purpose." Council of Europe, 1980. www.coe.int.

4 During the years 2004-2006 about €20 million were allocated to the Ukrainian partners involved in projects directed at the strengthening of transboundary and transnational cooperation between the EU and Ukraine within the framework of the EU programmes. Slovakia, Poland, and Hungary were financed under INTERREG, and Romania by PHARE.

5 The ENPI is a more flexible and policy-driven mechanism, as the allocation of funds depends on a country's needs and absorption capacity and its level of imple- 
Borders in Globalization Review | Volume 1 | Issue 1 | Fall 2019

Shaban, "Cross-Border Cooperation in the Carpathian Euroregion"

mentation of agreed reforms. As from 2014, the ENPI was replaced by the European Neighbourhood Instrument, which provides increased support to 16 partner countries to the east and south of the EU's borders.

6 CORLEAP is the political forum of local and regional authorities. It is the only EU platform that offers an opportunity to discuss the contribution by cities and regions in the development of the EaP.

7 According to the Working Plan of the Administrative Office of the Twinning Programme, there were 61 Twinning projects for 2013 in Ukraine.

8 Ministry of Foreign and European Affairs of the Slovak Republic. Information about Visegrad is also available here: http://visegradfund.org/home/

\section{Works Cited}

Casier, T. 2013. "Belgium, Luxembourg and the Netherlands". In M. David, J. Gower, \& H. Haukkala (eds), National perspectives on Russia. European foreign policy in the making? Routledge. 118-131.

David, F. R. 2003. Strategic management - concepts and cases. USA: Pearson Education.

Delcour, L. 2011. Shaping the post-Soviet space? EU policies and approaches to region-building. London: Ashgate.

Gasparini, A., \& E. Ferluga. 2005. "SWOT analysis in three cross-border areas. Strategies and actions to plan cross-border co-operation," ISIG Quarterly of International Sociology 19/2. URL: http://www.isig.it

Gasparini, A. eds. 2017. "The Walls between conflict and peace," International Comparative Social Studies 34. http://doi.org/ddkp.

Kolossov, V., \& Van Well, L. 2016. "Eastern Neighbourhood: territorial cooperation implies a common energy strategy" in P. Beckouche, P. Besnard, H. Pecout (eds). Atlas of challenges and opportunities in European Neighbourhoods. Paris: Springer International Publishing.

Kramsch, O., \& Hooper, B. (eds). 2004. Cross-border governance in the European Union. London and New York: Routledge.

Langbein, Y. 2015. Transnationalization and regulatory change in the EU's eastern neighbourhood: Ukraine between Brussels and Moscow. London: Routledge.

Laszlo, B. 2001. "The Organizational Structure of the Carpathian Euroregion" in B. Laszlo, Carpathian Euroregion. Borders in the Region - Cross-Border Co-operation. Debrecen: European Study Centre Programme of the University of Debrecen.

Liikanen, I., J. Scott, \& T. Sotkisiira (eds). 2016. The EU'S Eastern Neighbourhood: migration, borders and regional stability. London and New York: Routledge Series on Russian and East European studies.

Ludvig, Z. 2003. Hungarian-Ukrainian cross-border cooperation with special regard to Carpathian Euroregion and economic relations. Warsaw: Batory FOundation.
Makowski, J. 1993. Embankments on the Lower Vistula, historical shaping, present state and behavior during substantial freshets. IBW PAN, Gdansk [in Polish].

Mytryaeva, S. 2007. "Carpathian Euroregion as an instrument of Ukraine's Eurointegration strategy". In Regionality and/or Locality (pp. 122-136). Discussion Papers, Pecs Centre for Regional Studies.

Schimmelfennig, F., \& U. Sedelmeier. 2005. The Europeanization of Central and Eastern Europe. Ithaca: Cornell University Press.

Sotnikov, Y., \& I. Kravchenko. 2013. "Cross-border cooperation development of Ukraine: Forms and instruments of competitiveness increase". Economics and Management 18/1: 95-101. http://doi.org/ddkq

Stworzyszenie na Rzecz Euroregionu Karpackiego Euro-Karpaty (in Polish), 2002.

The Carpathian Euroregion Project: Institute for East-West Studies. Atlanta-Bardejov. https://www.eastwest.ngo/.

Takahashi, K. 2006. "Sub-regionalism in the border regions between the EU and Russia". In H. Taga \& S. Igeroshi, The new international relations of sub-regionalism: Asia and Europe. Routledge Studies.

Tanaka, H. 2006. "Carpathian Euroregion and cross-border governance". The Journal of Comparative Economic Studies 2: 59-80. Persistent URL: https://EconPapers. repec.org/RePEc:cos:epaper:v:2:y:2006:p:59-80

van Kersbergen, C. J., \& F. van Waarden. 2004. "Governance' as a bridge between disciplines: Cross-disciplinary inspiration regarding shifts in governance and problems of governability, accountability and legitimacy". European Journal of Political Research 43/2: 143-171. http://doi.org/far7v7

\section{Documents}

European Commission. 2003a. "Wider Europe-Neighbourhood: a New Framework for Relations with Our Eastern and Southern Neighbours". Brussels, COM (2003) 104 final.

European Commission. 2006. "European Neighbourhood and Partnership Instrument”.

Cross-Border Cooperation. Strategy Paper 2007-2013. Executive Summary of the ENPI CBC Strategy Paper.

Konstytucia Ukrainy [The Constitution of Ukraine]. 1996. http://zakon.rada.gov.ua/cgi-bin/laws/main.cgi?nreg $=254 \% E A \% 2 F 96 \% 2 D \% E 2 \% F O$.

On the Cross-Border Cooperation: Law of Ukraine of 24.06.2004. 1861-IV // Voice of Ukraine. 2004. http:// zakon.rada.gov.ua/cgi-bin/laws/main.cgi?nreg=1861-15.

Regulation (EC) No 1638/2006 of the European Parliament and of the Council of 24 October 2006.

Research Center of the Slovak Foreign Policy Association. 2019. http://www.sfpa.sk/en/.

Resolution of the Cabinet of Ministers of Ukraine No. 587 of 29 April 2002 "Some issues of the Cross-border Cooperation and Euroregions Development" (with 
Borders in Globalization Review | Volume 1 | Issue 1 | Fall 2019 Shaban, "Cross-Border Cooperation in the Carpathian Euroregion"

amendments and changes introduced in accordance with the CM Resolution No. 270 of March 1, 2003 and 1402 of September 4, 2003). http://mfa.gov.ua/ua.

Strategic Development Programme for the Carpathian Euroregion Interregional Association. 2004.

The Carpathian Euroregion Strategy 2020 \& Beyond (2015). Regional Development Association for the Carpathian Euroregion.

The Concept of the Common Development of the Ukraine's and Hungary bordering Territories, approved June 2003.

The Conference of the Regional and Local Authorities for the Eastern Partnership. The Annual Meeting. Tbilisi, 2014.
The Law of Ukraine for "Cross-Border Cooperation", official release, Supreme Council of Ukraine, N45, Art.499, 2004;

The Law of Ukraine "On Fundamentals of State Regional Policy”. 5 February 2015, no. 156-VIII1.

The Ukrainian Concept of the State Regional Policy. 2001.

The Strategy of Transboundary Cooperation Development in the Carpathian region "Carpathians 2003-2011", October 2003.

Zakon Ukrainy "Pro Formuvannya Mistsevyh Organiv Vlady i Samovryaduvannya" [The Law of Ukraine "On the making of the bodies of local power and self-government"]. (1994). http://zakon.rada.gov.ua/cgi-bin/ laws/main.cgi?nreg=3917-12. 